*ak RMIS View/Frint Document Cover Sheet tow

This document was retrieved from the Documentation and Records Manaqement (DRM) ISEARCH System. It is intended for Information only and may not be the most recent or updated version. Contact a Document Service Center (see Hanford Info for locations) if you need additional retrieval information.

Accession \#: D196022103

Document \#: SD-W314-PAP-001

Title/Desc:

SYSTEM SAFETY PROGRAM PLAN FOR PROJECT W-314 TANK FARM RESTORATION \& SAFE OPERATIONS

Pages: 17 


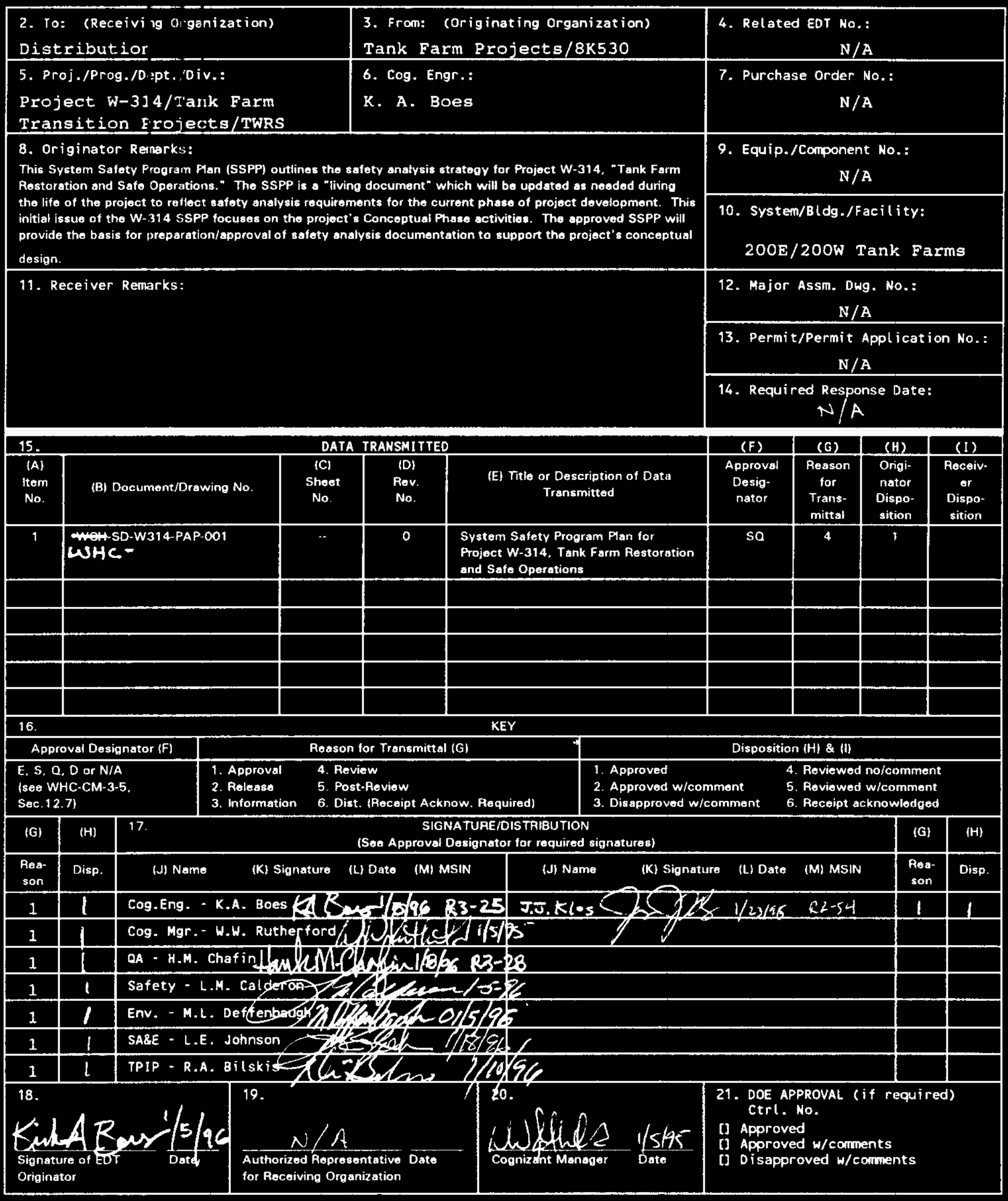




\title{
System Safety Program Plan for Project W-314, Tank Farm Restoration and Safe Operations
}

\author{
K. A. Boes \\ Westinghouse Hanford Company, Richland, WA 99352 \\ U.S. Department of Energy Contract DE-AC06-87RL10930 \\ EDT/ECN: 614535 \\ Org Code: $8 \mathrm{~K} 530$ \\ B\&R Code: EW3130010 \\ UC: 2030 \\ Charge code: N14PL \\ Total pages: 2314
}

Key Words: Project $\mathrm{W}-314$, Tank Farm Upgrades, Safety Planning, Unreviewed Safety Question, Conceptual Design, System Safety Program

\begin{abstract}
This system Safety Program Plan (SSPP) outlines the safety analysis strategy for Project W-314, "Tank Farm Restoration and Safe Operations." Project $W-314$ will provide capital improvements to Hanford's existing Tank Farm facilities, with particular emphasis on infrastructure systems supporting safe operation of the double-shell tank farms. This initial issue of the $\mathrm{w}-314$ SSPP focuses on near-term activities related to the project's Conceptual Design Phase, but is planned to be updated and maintained as a "living document" throughout the life of the project to reflect the current safety analysis planning for the Tank Farm Restoration and Safe Operations upgrades. This approved $W-314$ SSPP provides the basis for preparation/approval of all safety analysis documentation needed to support the project.
\end{abstract}

\footnotetext{
TRADEMARK DISCLAIMER. Reference herein to any specific commercial product, process, or service by trade name, trademark, manufacturer, or otherwise, does not necessarily constitute or imply its endorsement, recomendation, or favoring by the United States Government or any agency thereof or its contractors or subcontractors.

Printed in the United States of America. To obtain copies of this document, contact: WHC/BCS Document Control Services, P.O. Box 1970, Mailstop H6-08, Richland WA 99352, Phone (509) 372-2420; Fax (509) 376-4989.
}
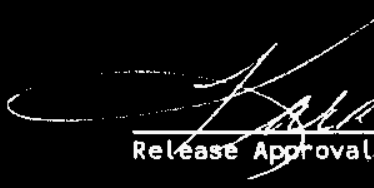

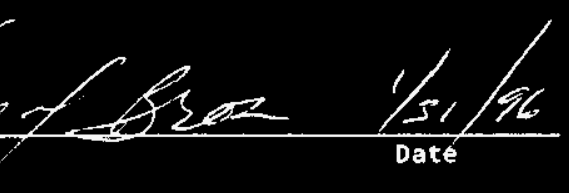

Approved for Public Release

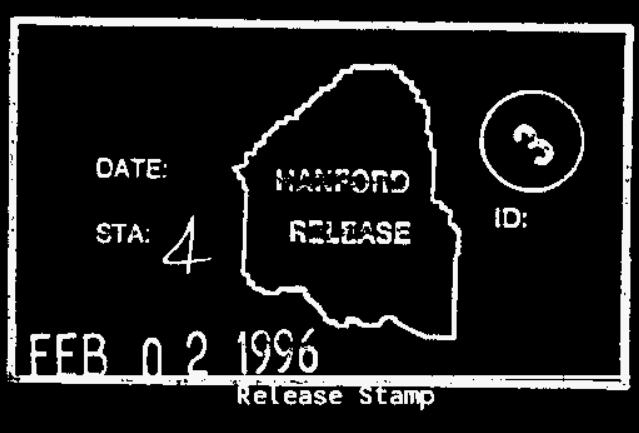


WHC-SD-W314-PAP-001, Rev. 0

\section{SYSTEM SAFETY PROGRAM PLAN \\ FOR}

PROJECT W-314

TANK FARM RESTORATION AND SAFE OPERATIONS

\section{Prepared for}

U. S. Department of Energy Richland Field Office

Richland, Washington

by

Westinghouse Hanford Company

Richland, Washington 99352 
WHC-SD-W314-PAP-001, Rev. 0

\section{TABLE OF CONTENTS}

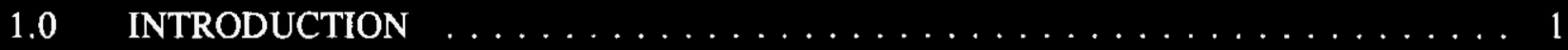

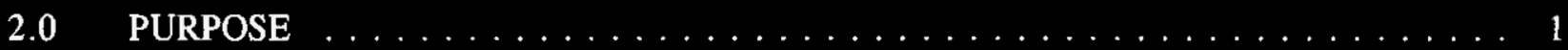

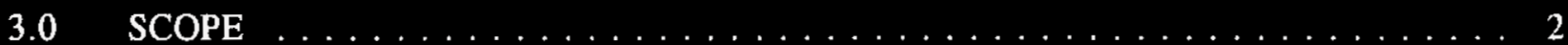

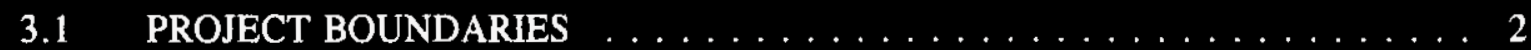

3.2 APPLICABLE STANDARDS AND GUIDES $\ldots \ldots \ldots \ldots \ldots \ldots \ldots$

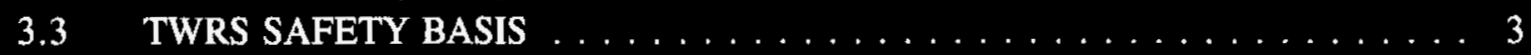

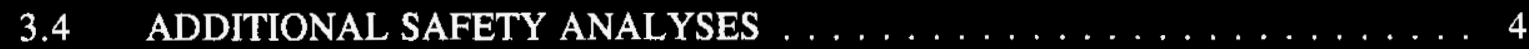

$4.0 \quad$ ROLES AND RESPONSIBILITIES $\ldots \ldots \ldots \ldots \ldots \ldots \ldots \ldots \ldots \ldots$

4.1 W-314 PROJECT TEAM . . . . . . . . . . . . . . . 4

4.2 TRANSITION PROJECTS INTEGRATION PROGRAM $\ldots \ldots \ldots \ldots \ldots \ldots$

4.3 SAFETY ANALYSIS AND ENGINEERING $\ldots \ldots \ldots \ldots \ldots \ldots \ldots \ldots$

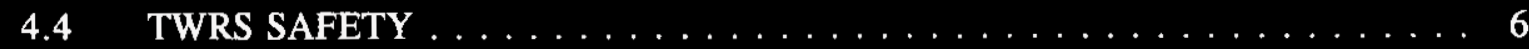

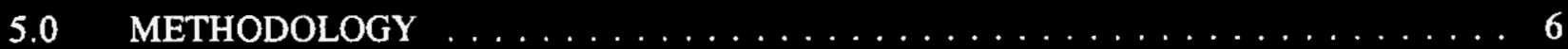

$5.1 \quad$ W-314 F\&OR DEVELOPMENT $\ldots \ldots \ldots \ldots \ldots \ldots \ldots \ldots \ldots$

$5.2 \quad$ W-314 ARCHITECTURAL TRADE STUDIES $\ldots \ldots \ldots \ldots \ldots \ldots \ldots$

$5.3 \quad W-314$ TEST SPECIFICATIONS DEVELOPMENT $\ldots \ldots \ldots \ldots \ldots \ldots$

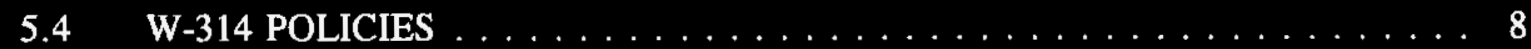

$5.5 \mathrm{~W}-314$ CONCEPTUAL DESIGN REPORT $\ldots \ldots \ldots \ldots \ldots \ldots \ldots$

$5.6 \quad$ W-314 DEPLOYMENT ANALYSIS $\ldots \ldots \ldots \ldots \ldots$

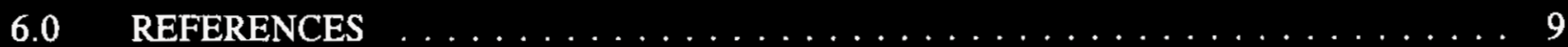

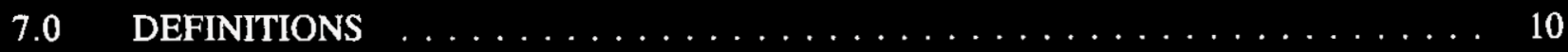




\section{SYSTEM SAFETY PROGRAM PLAN FOR PROJECT W-314 \\ TANK FARM RESTORATION AND SAFE OPERATIONS}

\subsection{INTRODUCTION}

The System Safety Program for Project W-314, "Tank Farm Restoration and Safe Operations," is based on the requirements of the Military Standard 882C "Systems Safety Program Requirements" (MIL-STD 1993). According to this standard, the principal objective of a System Safety Program is to ensure that safety, consistent with mission requirements, is designed into systems, subsystems, equipment, facilities and their interfaces and operation. The degree of safety achieved in a system depends directly on management emphasis. Management emphasis should be applied to safety during the system acquisition process and throughout the life cycle of each system, making sure mishap risk is understood and risk reduction is always considered in the management review process. A formal safety program that stresses early hazard identification, and elimination or reduction of associated risk to an acceptable level, is the principal contribution of effective system safety. The Project W-314 System Safety Program objectives, as presented in this System Safety Program Plan (SSPP), are to assure that:

a. Safety, consistent with mission requirements, is designed into the system in a timely, cost-effective manner.

b. Hazards associated with each system are identified, tracked, evaluated, and eliminated, or the associated risk reduced to an acceptable level throughout the entire life cycle of a system.

c. Actions taken to eliminate hazards or reduce risk to an acceptable level are documented.

d. Changes in design, configuration, or mission requirements are accomplished in a manner that maintains an acceptable risk level.

e. Actions are taken to minimize the use of hazardous materials and, therefore, minimize the risks and life cycle costs associated with their use.

f. Historical safety data, including lessons learned from other systems, are considered and used.

g. Retrofit actions required to improve safety are minimized through the timely inclusion of safety features during acquisition of a system.

\subsection{PURPOSE}

The purpose of this SSPP is to describe the tasks and activities of system safety management and system safety engineering required to identify, evaluate, or eliminate/control hazards associated with the construction, installation, and operation of the upgraded systems provided by Project W-314, and to include design features, when feasible, to reduce the risks associated with these hazards to acceptable levels. This plan provides a formal basis for the safety analysis activities to be undertaken during the life of the project in support of ensuring system safety. Initially, this plan focuses on the activities required to support the project's Conceptual Phase. The SSPP will be updated as needed and maintained current throughout the project's life cycle to reflect the Project W-314 System Safety Program requirements and activities needed to support the current project phase, i.e., Conceptual Phase, Title I Phase, Title II Phase, and, ultimately, installation. 


\subsection{SCOPE}

This SSPP applies to the activities associated with Project W-314, "Tank Farm Restoration and Safe Operations." The goal of this project is to support tank waste management operations by improving the reliability of essential tank infrastructure and safety-related systems, reducing onsite health and safety hazards, and supporting future waste retrieval and disposal activities. This will be accomplished by restoring and/or upgrading the existing tank farm facilities and systems. Due to their age, many infrastructure systems and components have either exceeded their useful service life; have deteriorated beyond repair and must be replaced to ensure continued reliable operation; or operate outside current environmental, health, and safety regulations or requirements.

The primary systems of concern to this project are: tank ventilation, instrumentation and control, waste transfer, and electrical power distribution. The nature of the project is such that most, if not all, of the upgrades will constitute replacement/refurbishment of existing tank farm infrastructure elements. Therefore, extensive or elaborate safety documentation should not be required, but rather, the safety basis for the project will be evaluated via the Unreviewed Safety Question (USQ) process, and documented as addenda or revisions to the primary safety documentation for the affected facilities.

\subsection{PROJECT BOUNDARIES}

The details of the scope of the project can be found in the Project W-314 Upgrade Scope Summary Report (USSR) (WHC 1996). The scope focuses mainly on restoration of Hanford's double shell tank (DST) infrastructure systems, and includes upgrades to selected tank ventilation systems, electrical power systems, and waste transfer systems, as well as extensive upgrades to the DST instrumentation/control (e.g., leak detection/alarms, ventilation monitoring/control, tank level measurement, master pump shutdown, etc.) and information management systems. The project scope also includes limited upgrades to selected single shell tank and double contained receiver tank (DCRT) systems. Further description of the project scope is provided in the W-314 USSR document.

\subsection{APPLICABLE STANDARDS AND GUIDES}

Project W-314 modifications shall be designed in accordance with the safety requirements defined in the project's Preliminary Design Requirements Document (PDRD) (WHC 1995a). These requirements represent design constraints within which the project's design and the System Safety Program must operate. These constraints are promulgated to the project, along with additional design requirements and constraints, via the PDRD and its supporting Functions and Operations Requirements (F\&OR) documentation.

The safety basis for Project W-314 shall be documented according to the following:

- DOE Order 5480.21, Unreviewed Safety Questions

- DOE Order 5480.22, Technical Safety Requirements

- DOE Order 5480.23, Nuclear Safety Analysis Reports

- WHC-CM-4-46, Safety Analysis Manual 


\subsection{TWRS SAFETY BASIS}

The following documents comprise the majority of the safety basis for TWRS, as it is presently defined:

- WHC-SD-WM-ISB-001, Rev. 0i, chapter 6, "Hanford Site Tank Farm Facilities Interim Safety Basis"

- WHC-SD-WM-OSR-004, Rev. 1, "Aging Waste Facilities Interim Operational Safety Requirements"

- WHC-SD-WM-OSR-005, Rev. 0, "Single Shell Tank Interim Operational Safety Requirements"

- WHC-SD-WM-OSR-016, Rev. 0, "Double Shell Tank Interim Operational Safety Requirements"

Modifications proposed by Project W-314 will be compared to the applicable portions of this safety basis to evaluate the need for USQ determinations and/or additional safety analysis, and to designate the affected facility whose safety documents will ultimately need to be modified to enable upgrades. A formal record of all analyses, assessments, and decisions concerning the Project W-314 safety basis shall be maintained and updated as required.

Westinghouse Hanford Company (WHC) is currently involved in a major effort to prepare an Final Safety Analysis Report (FSAR) for the tank farms that is consistent with the requirements of DOE Order 5480.23, Nuclear Safety Analysis Reports (DOE 1995a). Upon approval, this new FSAR will become the safety basis for the tank farms and will supersede the above documents. This safety analysis may have a major impact on determination of safety classifications and the ultimate destination for the Project W-314 safety basis documentation. As the new tank farm FSAR is developed, the project will review it to identify any impacts to the project's design basis.

\subsection{ADDITIONAL SAFETY ANALYSES}

In addition to the TWRS safety basis documentation cited above, the Project W-314 System Safety Program will also utilize applicable analyses and information from other related tank farm safety documentation, such as:

- WHC-SD-W211-PSE-002, Rev. 0, "Preliminary Safety Evaluation, Initial Tank Retrieval Systems, Project W-211"

- WHC-SD-W211-SEL-002, Rev. 0, "Safety Equipment List, Initial Tank Retrieval Systems, Project W-211"

- WHC-SD-W058-PSE-001, Rev. 0, "Preliminary Safety Evaluation, Replacement of Cross-Site Transfer System, Project W-058"

WHC-SD-W058-PSAR-001, Rev. 1, "Replacement of Cross-Site Transfer System, Preliminary Safety Analysis Report, Project W-058" 
- WHC-SD-W030-PSAR-001, Rev. 0, "Preliminary Safety Analysis Report, Tank Farm Ventilation Upgrades, Project W-030"

- WHC-SD-SEL-020, Rev 2, “Aging Waste Facilities Interim Safety Equipment List”

- WHC-SD-SEL-026, Rev 1, “Double Shell Tanks Interim Safety Equipment List”

- WHC-SD-WM-SEL-027, Rev. 0-A, "Single Shell Waste Tanks Interim Safety Equipment List"

\subsection{ROLES AND RESPONSIBILITIES}

The roles and responsibilities of the various major organizational entities which will be involved in W-314 System Safety Program activities during the Conceptual Phase of the project are described below and listed in Table 1.

\subsection{W-314 PROJECT TEAM}

The W-314 Project Team is responsible for all design media and documentation associated with the upgrades identified in the W-314 USSR document. The W-314 System Safety Program, as outlined in this plan, will be implemented by the W-314 Project Team in conjunction with the design development activities to provide the safety basis for the upgrades involved. It is the Project Team's responsibility to produce the documentation, analyses, etc., necessary to demonstrate compliance with applicable safety and safety analysis requirements so that the upgrades can be accomplished without compromising the safety margins of the affected facilities.

The TWRS systems engineering approach, as defined in the TWRS Systems Engineering Standard (DOE 1995b) and the Project W-314 Systems Engineering Management Plan (WHC 1995b), is being utilized to derive the requirements for the upgraded systems. The requirements will be documented in Requirements Allocation Sheets (RAS) and supporting Alternative Generation Analysis reports (i.e., architectural trade studies). These studies and the resulting reference architecture development will also be performed by the Project Team. The Project Team will provide the necessary design analyses for determining failure modes and effects, and for assigning safety class or verifying existing classifications, in conjunction with the W-314 architecture development tasks. This will help minimize late design adjustments and provide optimal safety class values. Establishing system functional behaviors that will ensure safety will be accomplished by close association between the W-314 Architectural Development subgroup and the W-314 F\&OR subgroup (both subgroups are elements of the Project Team).

The W-314 Project Team will be responsible for ensuring that USQ determinations and/or other safety documentation are done as needed to support the proposed architectural decisions. The Project Team will interface with the TWRS Independant Safety oversight and the TWRS Safety and Technical Integration organization via a project single point-of-contact. This point-of-contact will be responsible for proper coordination of the safety review process, including scheduling reviews, briefing reviewers, and assuring timely and appropriate comment resolution. Formal safety review and approval will be obtained as required by the Standard Engineering Practices Manual (WHC 
1995c) for all project design media which constitute the baseline and are released as formal documents. Safety reviews will also be solicited as appropriate for intermediate project documents such as USQ evaluations, safety class determinations, safety sections of the Alternative Generation Analysis reports, and any safety-related deviations or waivers sought by the Project Team. It is intended that all items of this nature will be coordinated with TWRS Independant Safety and the TWRS Safety and Technical Integration via the Project Team's single point-of-contact.

\subsection{TRANSITION PROJECTS INTEGRATION PROGRAM}

The Transition Projects Integration Program (TPIP) is responsible for defining the scope and upper-level requirements baseline for Project W-314. The TPIP office has the following major functions (WHC 1995d):

- Ensure that the scope of work for Tank Farm Transition Projects is well defined and justified, and provide the necessary direction, oversight, and measurement of progress for projects assigned to the TPIP office.

- Identify, develop, and maintain interfaces among, and effectively integrate, TWRS and other Hanford Site projects and activities that might directly or indirectly affect the successful performance and completion of Tank Farms Transition Projects.

- Ensure that changes are made as needed to the various TWRS safety basis documents (e.g., Interim OSRs, Safety Equipment Lists, Safety Analysis Reports, etc.) as needed to enable implementation of the Tank Farm Transition Projects.

\subsection{SAFETY ANALYSIS AND NUCLEAR ENGINEERING}

WHC's Safety Analysis and Nuclear Engineering (SA\&NE) organization will be responsible to provide guidance and review of the Project W-314 System Safety Program documentation, as delineated in the Safety Analysis Manual (WHC 1995e), and shown in Table 1. Additional technical assistance may be requested from this group by the Project Team, if needed.

\subsection{TWRS SAFETY}

The TWRS Safety independant oversight organization will support the Project W-314 design development by providing safety reviews of project documentation/design media in the areas of radiation protection, industrial hygiene, safety, fire protection, and nuclear safety. This organization will also review and approve any changes to the project's SSPP.

\subsection{TWRS SAFETY AND TECHNICAL INTEGRATION}

The TWRS Safety and Technical Integration organization will support the Project W-314 design development by assisting in implementation of the USQ process, reviewing and approving of the outcome of the USQ determinations, and appraising the project of changes in the TWRS safety basis. 
TABLE 1. ROLES AND RESPONSIBILITIES*

\begin{tabular}{|l|c|c|c|c|c|}
\hline & $\mathrm{r}$ & $\mathrm{a}$ & $\mathrm{a}$ & $\mathrm{a}$ & $\mathrm{p}$ \\
\hline $\mathrm{USQ}$ & $\mathrm{r}$ & $\mathrm{i}$ & $\mathrm{i}$ & $\mathrm{i}$ & $\mathrm{p}$ \\
\hline $\begin{array}{l}\text { Preliminary Hazards } \\
\text { Analysis, Failure Modes \& } \\
\text { Effects Analysis, } \\
\text { Hazardous Operability, etc. }\end{array}$ & $\mathrm{r}$ & $\mathrm{a}$ & $\mathrm{i}$ & $\mathrm{a}$ & $\mathrm{p}$ \\
\hline Waivers/Deviations & $\mathrm{r}$ & $\mathrm{r}$ & $\mathrm{i}$ & $\mathrm{r}$ & $\mathrm{p}$ \\
\hline $\begin{array}{l}\text { Safety sections of Trade } \\
\text { Studies }\end{array}$ & & & & & \\
\hline
\end{tabular}

$* \mathrm{p}=$ prepare or conduct

$\mathrm{r}=$ review

$a=$ approve and/or issue

$\mathrm{i}=$ inform

\subsection{METHODOLOGY}

In a typical project the design development process follows a sequenced approach. The first step is the Conceptual Phase, which normally results in the preparation of a Conceptual Design Report (CDR) describing a design concept that meets the applicable design requirements and is used to establish the bounding cost and schedule baselines for the project. The CDR is usually accompanied by a Preliminary Safety Evaluation (PSE), which assesses the proposed design concept against the existing safety envelope for the affected facility(ies). The purpose of the PSE is to ensure that any significant hazards associated with the design concept presented in the CDR are evaluated and that appropriate cost considerations for eliminating/controlling those hazards are identified for inclusion in the project cost estimate. The PSE also supports the subsequent development of more detailed safety analysis documentation (e.g., Preliminary Safety Analysis Report), as necessary to authorize the start of construction (WHC 1995e).

However, because Project W-314 is intended to replace/restore existing infrastructure systems and is not expected to introduce any significant new hazards to the tank farm environment, and because the project is the first of its kind to implement the TWRS systems engineering process for development of design requirements and architecture, a slightly different approach is planned for the conceptual design development and for evaluating the proposed upgrades for safety impacts.

During the W-314 Conceptual Phase, the W-314 Project Team will utilize the TWRS systems engineering process to develop a conceptual architecture which satisfies the technical requirements baseline and supports development of firm cost and schedule estimates for the project. This approach will lead to the development of a W-314 Design Configuration Baseline (DCBL) package, consisting of upper-level technical specifications and various supporting documentation, which will become the 
basis for initiating the next major phase of the project, Preliminary (Title I) Design. As an interim step in completing the W-314 DCBL, the Project Team will prepare and issue a CDR for the project based on preliminary systems engineering products. The CDR will present a reference conceptual architecture for the Project W-314 upgrades and will serve as the initial basis for approving/validating the W-314 cost and schedule baselines. Upon completion of the W-314 DCBL, any changes to the project's technical approach and/or cost and schedule baselines will be reconciled with the initial CDR baselines. A discussion of the planned System Safety Program tasks associated with the Project W314 Conceptual Phase work is presented in the following sections.

\subsection{W-314 F\&OR DEVELOPMENT}

The W-314 F\&OR database development activity will provide a framework of functions and requirements that facilitates an efficient top-down system architecture development in an iterative manner. The purpose of the database is to capture raw and integrated information developed throughout the life cycle of that process. Two important ingredients of this process are the development of Requirement Allocation Sheets (RASs) and Design Constraint Sheets (DCSs). A RAS is initially used to define and document the performance requirements for identified functions. The level of detail shown on each RAS will be consistent to support the function level under consideration. In the same way that the RAS captures performance requirements of the system, a DCS holds information on the external constraints the system has to comply with. System safety personnel assigned to the W-314 Project Team will work closely with the F\&OR subgroup to provide guidance in establishing system functional behaviors which will help to ensure safety. In particular, the objective of this early safety engineering input is to arrive at a system architecture which contains the optimal safety features, built into the design from the beginning. Obtaining direct safety input from a design team member, rather than depending on an after-the-fact review of the design, will make the conceptual design effort more efficient. When necessary, special engineering studies may be produced to document important safety findings/recommendations.

\subsection{W-314 ARCHITECTURAL TRADE STUDIES}

The alternative architectures developed for Project W-314 by the Project Team will be evaluated against the following:

1) Adequacy in meeting the technical (including safety) requirements imposed on the alternative architecture

2) Adequacy, relative to other proposed alternatives, in minimizing life cycle costs

Personnel experienced in analyzing designs for failure modes and effects and assigning safety class values will work directly with the W-314 Architectural Development subgroup to provide guidance on how the proposed architectures can and/or need to be adjusted to ensure that necessary safety features are built into the design from the beginning. The W-314 trade studies will provide a check on the functional requirements developed for the affected architecture, and will "fill-in" any system element technical requirements not previously identified, and address any inconsistent or missing design constraints to ensure safety has been included as a consideration. System safety personnel assigned to the Project Team will review the options proposed in the trade studies and provide a safety assessment on the options. All architectural trade studies used as a basis for the W314 conceptual design will include a section describing the safety related aspects of the study, and demonstrating that these aspects have been given due consideration. 
WHC-SD-W314-PAP-001, Rev. 0

\subsection{W-314 TEST SPECIFICATIONS DEVELOPMINT}

Depending upon safety class, testing/analysis may be required for certain systems, structures, and components, to verify their design capabilities. System safety personnel assigned to the Project Team will assist and provide safety input/recommendations for the level of detail for such testing/analysis.

\section{$5.4 \quad$ W-314 POLICIES}

Establishing written policies will provide requirements to the designer resulting in an end product which the user can maintain, repair, test, etc., in an acceptable, cost effective manner. As these policies are prepared, the Project Team's system safety personnel will review them to ensure due safety consideration.

\subsection{W-314 CONCEPTUAL DESIGN REPORT}

The W-314 CDR will present a reference conceptual architecture for the Project W-314 upgrades and will serve as the initial basis for approving/validating the W-314 cost and schedule baselines. The proposed tank farm upgrades identified in the CDR will be evaluated for impacts to the existing safety basis using the established USQ evaluation process. The USQ safety reviews will be performed in accordance with WHC-IP-0842, TWRS Administration, Vol IV, Section 5.4 (WHC1995f). The USQ evaluation, performed in lieu of a project PSE, will be included as supporting information in the W-314 CDR document.

\subsection{W-314 DEPLOYMIENT ANALYSIS}

As reference architectures are further developed during the W-314 DCBL development process, analyses will be conducted to evaluate the effectiveness with which the architecture can be fabricated and installed in the field (an activity referred to as "deployment analysis"). Upon completion of the W-314 DCBL, any changes to the project's technical approach and/or cost and schedule baselines will be reconciled with the initial CDR baselines. In addition, the USQ evaluations performed in support of the CDR will be reviewed and updated, as necessary, to reflect the assessment of safety impacts based on the DCBL technical package. All USQ determinations will be formally documented, reviewed, and issued as supporting documentation. 
WHC-SD-W314-PAP-001, Rev. 0

\subsection{REFERENCES}

1. DOE 1995a, “Nuclear Safety Analysis Reports”, DOE Order 5480.23, US Department of Energy, April 30, 1992.

2. DOE 1995b, "TWRS System Engineering Standard", DOE/RL-95-12 (rev AE), US Department of Energy, Richland Office, April 3, 1995.

3. MILSTD 1993, "System Safety Program Requirements”, MIL-STD-882C, US Department of Defense, January 19, 1993.

4. WHC 1996, Letter, R. A. Bilskis to W. W. Rutherford, "Project W-314 Upgrade Scope Summary Report”, 77680-96-006, January 16, 1996.

5. WHC 1995a, WHC-SD-W314-DRD-001, "Preliminary Design Requirements Document for Project W-314", Rev 0, Westinghouse Hanford Company, June 28, 1995.

6. WHC 1995b, WHC-SD-W314-SEMP-001, “Systems Engineering Management Plan for Project W-314, Tank Farm Restoration and Safe Operations (TFRSO)”, Westinghouse Hanford Company, draft dated August 1, 1995.

7. WHC 1995c, WHC-CM-EP-6-1, EP-1.7, "Standard Engineering Practices, Engineering Document Approval and Release Requirements", Westinghouse Hanford Company, (most recent revision)

8. WHC 1995d, "Transition Projects Integration Program Plan", Westinghouse Hanford Company, draft dated November 1995.

9. WHC 1995e, WHC-CM-4-46, "Safety Analysis Manual”, Westinghouse Hanford Company, (most recent revision)

10. WHC 1995f, WHC-IP-0842, Vol IV, Section 5.4, “TWRS Administration”, Westinghouse Hanford Company 


\section{WHC-SD-W314-PAP-001, Rev. 0}

\subsection{DEFINITIONS}

Condition. An existing or potential state such as exposure to harm, toxicity, energy source, activity, etc.

Hazard. A condition that is prerequisite to a mishap.

Hazard Probability. The aggregate probability of occurrence of the individual events that create a specific hazard.

Hazard Severity. An assessment of the consequences of the worst credible mishap that could be caused by a specific hazard.

Hazardous Material. Anything that due to its chemical, physical, or biological nature causes safety, public health, or environmental concerns that result in an elevated level of effort to manage.

Mishap. An unplanned event or series of events resulting in death, injury, occupational illness, or damage to or loss of equipment or property, or damage to the environment.

Risk. A quantitative or qualitative expression of possible loss which considers both the probability that a hazard will cause harm and the consequences of that event.

Risk Assessment. A comprehensive evaluation of the risk and its associated impact.

Safety. Freedom from those conditions that can cause death, injury, occupational illness, or damage to or loss of equipment or property, or damage to the environment.

Subsystem. An element of a system that, in itself may constitute a system.

System. A composite, at any level of complexity, of personnel, procedures, materials, tools, equipment, facilities, and software. The elements of this composite entity are used together in the intended operational or support envirohment to perform a given task or achieve a specific purpose, support, or mission requirement.

System Safety. The application of engineering and management principles, criteria, and techniques to optimize all aspects of safety within the constraints of operational effectiveness, time, and cost throughout all phases of the system life cycle.

System Safety Engineering. An engineering discipline requiring specialized professional knowledge and skills in applying scientific and engineering principles, criteria, and techniques to identify and eliminate hazards, in order to reduce the associated risk.

System Safety Management. A management discipline that defines system safety program requirements and ensures the planning, implementation and accomplishment of system safety tasks and activities consistent with the overall program requirements. 
WHC-SD-W314-PAP-001, Rev. 0

System Safety Program. The combined tasks and activities of system safety management and system safety engineering implemented by acquisition project managers.

System Safety Program Plan. A description of the planned tasks and activities to be used to implement the required system safety program. This description includes organizational responsibilities, resources, methods of accomplishment, milestones, depth of effort, and integration with other program engineering and management activities and related systems. 
DISTRIBUTION SHEET

\begin{tabular}{|c|c|c|c|c|c|}
\hline \multirow{2}{*}{$\begin{array}{l}\text { To } \\
\text { DISTRIBUTION }\end{array}$} & \multirow{2}{*}{\multicolumn{3}{|c|}{$\begin{array}{l}\text { From } \\
\text { K. A. Boess }\end{array}$}} & \multicolumn{2}{|l|}{ Page 1 of 1} \\
\hline & & & & \multicolumn{2}{|c|}{ Date $01 / 30 / 96$} \\
\hline \multicolumn{4}{|l|}{ Project Title/Work Order } & \multicolumn{2}{|c|}{ EDT No. 614535} \\
\hline \multicolumn{4}{|c|}{$\begin{array}{l}\text { System Safety Program Plan for Project W-314, "Tank Farm } \\
\text { Restoration and Safe Operations," WHC-SD-W314-PAP-001, Rev. } 0\end{array}$} & \multicolumn{2}{|l|}{ ECN No. } \\
\hline Name & MSIN & $\begin{array}{c}\text { Text } \\
\text { With All } \\
\text { Attach. }\end{array}$ & Text Only & $\begin{array}{l}\text { Attach./ } \\
\text { Appendix } \\
\text { Only }\end{array}$ & $\begin{array}{l}\text { EDT/ECN } \\
\text { Only }\end{array}$ \\
\hline
\end{tabular}

R. A. Bilskis

K. A. Boes

S. R. Briggs

L. M. Calderon

H. M. Chafin

M. L. Deffenbaugh

M. A. delamare

G. L. Dunford

H. P. Fox

R. L. Golberg

J. D. Guberski

J. L. Homan

S. E. Hulsey

M. N. Islam

R. W. Jacobson

L. E. Johnson

R. J. Kidder

J. J. Klos

J. T. Koberg

J. R. Kriskovich

C. E. Leach

R. W. Mattichak

D. L. McGrew

G. Z. Morgan

J. E. Navarro

L. G. Peck

G. M. Ramin

M. L. Ramsay

R. W. Reed

M. D. Rickenbach

W. E. Ross

M. J. Royack

W. W. Rutherford

C. E. Shipler

A. B. Sidpara

P. L. Smith

R. J. Swan

J. D. Thomson

J. E. Truax

K. R. Welsch

J. H. Wicks

S. U. Zaman

Project Files

\begin{tabular}{|c|c|}
\hline R2 -88 & $\mathbf{x}$ \\
\hline R3 -25 & $\mathbf{x}$ \\
\hline R3-25 & $\mathrm{X}$ \\
\hline R3-01 & $\mathrm{x}$ \\
\hline R3 - 28 & $x$ \\
\hline$R 1-52$ & $x$ \\
\hline R3-25 & $\mathrm{x}$ \\
\hline $\mathrm{A} 2-34$ & $\mathrm{x}$ \\
\hline R2 -88 & \\
\hline R3 -25 & $\mathrm{X}$ \\
\hline$R 1-52$ & $\mathrm{x}$ \\
\hline H5-09 & $\mathrm{x}$ \\
\hline R3-08 & $\mathrm{X}$ \\
\hline R3-08 & $x$ \\
\hline$R 1-09$ & $\mathbf{x}$ \\
\hline A2 -25 & $\mathrm{x}$ \\
\hline$A 2-25$ & $\mathrm{x}$ \\
\hline$R 2-54$ & $\mathrm{x}$ \\
\hline G3-17 & $x$ \\
\hline$s 2-24$ & $\mathrm{x}$ \\
\hline$A 2-34$ & $\mathrm{x}$ \\
\hline R3-25 & $\mathrm{x}$ \\
\hline R3 - 25 & $\mathrm{x}$ \\
\hline$A 6-54$ & $\mathrm{x}$ \\
\hline s7 -52 & $\mathrm{x}$ \\
\hline $\mathrm{H} 6-35$ & \\
\hline $57-54$ & $\mathrm{x}$ \\
\hline s7-52 & $\mathrm{x}$ \\
\hline$R 1-51$ & \\
\hline G3-17 & $\mathrm{x}$ \\
\hline$s 5-07$ & \\
\hline $57-54$ & \\
\hline R3-25 & $\mathrm{x}$ \\
\hline $\mathrm{R} 1-09$ & \\
\hline $57-54$ & \\
\hline R3-08 & $\mathrm{x}$ \\
\hline H6-21 & $x$ \\
\hline H6-35 & \\
\hline$R 2-50$ & \\
\hline H6-26 & $\mathrm{x}$ \\
\hline R2 -50 & \\
\hline$R 3-08$ & $x$ \\
\hline G6-51 & $\mathrm{x}$ \\
\hline
\end{tabular}

$\mathrm{x}$

$\mathrm{x}$

$\mathrm{x}$

$\mathrm{x}$

$\mathrm{x}$

$\mathrm{x}$

$x$

$\mathrm{x}$

$\mathbf{x}$ 